\title{
The Influence of Organizational Commitment, Organizational Culture, and budgeting to the Zakat Institution Accountability
}

\author{
Hani Werdi Apriyanti ${ }^{1}$, Depi Indriyani ${ }^{2}$ \\ Universitas Islam Sultan Agung, Jl. Raya Kaligawe Km 4 Semarang, Indonesia ${ }^{1,2}$ \\ \{hani.apriyanti@unissula.ac.id ${ }^{1}$,deviindriyani@std.unissula.ac.id²\}
}

\begin{abstract}
Accountability of the Zakat Institution (OPZ) is a manifestation of the tasks that must be fulfilled by the zakat institution for the management and distribution of the zakat funds. This study aims to determine "the effect of organizational commitment, organizational culture and budgeting on the accountability of zakat institution (OPZ)". The hypothesis proposed is organizational commitment, organizational culture and budget targets have a significant positive effect on the accountability of zakat institution (OPZ). This type of research is quantitative. The population was OPZ in Central Java with a sample of 50 respondents using a purposive sampling method. The results showed that organizational commitment and organizational culture variables had a significant positive effect on the accountability of zakat institution (OPZ). The variable of the budget target has no significant negative effect on the accountability of Zakat Institution (OPZ).
\end{abstract}

Keywords: Organizational commitment, organizational culture, budgeting, accountability

\section{Introduction}

The phenomenon of the potential gap of zakat and the realization of zakat receipts in Indonesia since the beginning of State independence up to now shows that people who are subject to compulsory zakat on property and income ownership (muzakki) have not been optimal in fulfilling their obligation to pay zakat. Data from the National Amil Zakat Agency (BAZNAS) in 2017, shows that the potential for national level zakat receipts reached 286 trillion rupiah, while the realization in 2018 was around 8.1 trillion rupiah or around $2.8 \%$ of its total potential (Baznas.go.id). The low level of public trust, especially from muzakki (people who are obliged to pay zakat) to zakat management organizations, is one of the main reasons classified by BAZNAS related to the potential gap in the receipt or collection of zakat results and their re-activation in the community. Thus, it can be said that muzakki demands more evidence on the management of community funds, the collection and distribution of zakat proceeds entrusted to zakat management organizations (Sudibyo, 2018).

To foster zakat trust to the government, the accountability of zakat institution (OPZ) and the Indonesian Accountants Association (IAI) seek the strategies and make their best contributions. IAI, which acts as an accounting professional organization in Indonesia, is 
doing its best and realizing its contribution by issuing Financial Accounting Standards (PSAK) No. 109 in 2010. This PSAK is intended to regulate the accounting for zakat, infaq, waqaf, and shadaqah, its contents regarding measurement standards, publication of reports, presentation and responsibilities of related parties. Meanwhile, the government takes an optimization strategy for receiving national zakat by ratifying the Republic of Indonesia Law No. 38/1999. Therefore, zakat can be collected from parties or organizations formed by the central government by meeting and complying with the guidelines and qualification standards (Badan Amil Zakat), or zakat bodies which compiled by private parties, especially local communities (Lembaga Amil Zakat). Furthermore, in 2011, the Law on zakat management No. 38 was replaced with Law No. 23/2011 (zakat outlook, 2017).

Today, accountability in non-profit organizations is a unique topic, due to its very different behavior and characteristics from profit organizations (Siskawati, et al. 2014). In carrying out activities and operational routine, Amil (parties who collect, store, safeguard, record, and distribute zakat) at OPZ receives donations from donors through a fundraising program. Thus, to maintain trust, muzakki who have donated, OPZ managers are expected to provide the presentation and writing of financial statements in accordance with PSAK 109 for the preparation of accountable OPZ financial statements.

Accountability is defined in terms of Islamic accounting, which is a method and system that is applied to produce a correct disclosure according to the qualifications or rules that are enforced. Accountability and disclosure to Allah, government, muzakki, public and nature. Accountability has a role for muhtasib (accountant) who states that sharia laws / regulations are carried out as tools for the welfare of the people (Tapanjeh, 2009). Organizational commitment is defined as the intention to accept certain goals and values in an organization. Previous research conducted by (Maghfiroh et al. 2012) revealed that organizational commitment has a significant effect on accountability, then this is strengthened by research (Hardiyanto et al. 2016) which states that organizational commitment has no significant effect on accountability.

Schein (1992) defines organizational culture as a description of the basic thinking that is shared by a group of people both on a large or small scale who they previously believed to be true of the pattern as a way to solve problems. (Christina, et al. 2012) revealed that organizational culture has a positive effect on accountability of OPZ. This is further strengthened by (Hamidi 2013) which states that organizational culture has no effect on accountability of OPZ. Clarity of budget targets in social institutions is defined as measurement benchmarks that explain the extent to which the goals and visions of social organizations can be understood by the person or amil entrusted with the achievement of the organizational goals (Surahono, 2006). (Pri-madoni et al. 2014) shows that clarity of budget targets has a positive effect on OPZ accountability. This research is also corroborated by (Laksana et al. 2014) which reveals that clarity of budget targets has a negative effect on OPZ accountability.

Based on the findings and results that have been carried out by previous studies, it shows that there are differences in the results of the research, so the researcher is encouraged to reexamine on what internal factors affect accountability of OPZ. Based on previous research by (Hardianto 2018), it shows that there are several factors that are considered to be able to influence the accountability of the internal environment in a zakat management institution, including integrity, ethical values, organizational commitment, leadership philosophy, and spirituality.This research develops from previous research conducted by (Hardiyanto 2018), (Setyorini et al. 2015), (Arjuna, et al. 2019), (Aisyah, et al. 2020) (Nurji, et al. 2017), and (Laksana, et al. 2014). The difference between this research and previous researches is the 
added variable of organizational culture and clarity of budget goals. This study combines the three independent variables previously studied separately. This is due to suggestions from previous researchers that it is necessary to carry out studies and research in the future that dig deeper into other internal factors that affect the accountability of OPZ.

Based on the explanation above, we as researchers focus on conducting more in-depth research on internal factors that affect accountability of OPZ and re-examining the organizational commitment variable and adding the two variables, namely organizational culture and clarity of budget targets. Researchers used different research methods and also refined the data by visiting respondents directly in the process of distributing and collecting questionnaires by directly interviewing respondents who reflected more honest answers.

\section{Literature Review and Hypothesis Development}

\subsection{Literature Review}

Sharia enterprise theory (SET), is a concept of accountability that contains principles for realizing accountability to Allah SWT, humans and nature (Zakiy, 2016). Sharia Enterprise Theory (SET) positions Allah SWT as the first mandate principle, and other resources are a form of mandate from Allah SWT, who has the responsibility to carry out organizational goals based on Al-Qur'an, sharia law, fiqh, ijma, and hadith to achieve falah (Firmansyah, 2016). Based on the Sharia Enterprise Theory, OPZ is positioned as a tool used by stakeholders to implement socio-economic principles by fully knowing the duties and obligations of Allah SWT, muzakki, the community, and other parties involved in these activities as a form of worship (Apriyanti, 2016). SET in the theory of zakat describes a balanced relationship, namely interconnected positions that are related to the values contained in Islamic accounting such as humanism, truth, feminism, spirituality, material values, individual and group values (Triyuwono 2006).

In this research, SET can be linked with zakat management organizations, namely regarding the form of stakeholder responsibility (Amil Zakat) to Allah SWT, shareholders (people / bodies obliged to zakat), society, mustahik (8 groups of Zakat Recipients) and the Universe. As a body that collects and distributes zakat funds, amil zakat is required to be able to provide accountability and truth (transparency) for each account in the financial statements prepared and issued by OPZ as evidence of responsibility during a certain period.

Theory of Planed Behavior (TPB) was popularized by (Aizen, 1991) which describes the relationship between attitude and action. TPB is a continuation or an indication of Theory of Reason Action (TRA). TRA itself explains that if a person's intention to behave is formed and proceeds from several main causes and indicators, namely attitude toward behavior and subjective norms (Fishbein and Ajzen, 1975). According to (Panjaitan, 2017), Theory of Planned Behavior (TPB) is divided into 3 types; attitude towards behavior, which is the phase of a person in evaluating whether the behavior is appropriate to do or not which is determined by one's beliefs individually. Second, is subjective norm, which is measured by a person's perception in which the people within the scope of the interaction agree with certain behaviors that are used as standards for certain behavior or not. Third, perceived behavioral control, which states that the stronger the controlling that amil has to display accountability and transparency of zakat funds, the higher the trust by muzakki.

Fund theory is part of the theory of entities, and groups of assets, liabilities and related things, which govern the use of assets from non-profit or social organizations. Thus, fund theory views an organization as composed of economic resources (funds) and the obligations 
and restrictions related to the source of funds or assets owned are managed properly and effectively. The accounting unit in defining assets and the use of assets is carried out prudently and effectively. In fund theory, it is not only aimed at how funds are obtained and collected but the focus is also on how an agency then in the best possible way provides appropriate and credible disclosures. This theory states the disclosure of how assets are not only stored but also used in a variety of predetermined ways (Chariri, 2007).

Accountability is a method of accountability for management or the recipient of the mandate to the trustee for the management of the resources entrusted to him either vertically or horizontally (Endahwati, 2014). In OPZ, the obligation to Allah (vertical responsibility) means that all activities in the zakat management institution without exception, including recording accounting information at the zakat management institution are a form of accountability to Allah SWT. Thus, the process of managing funds, as well as recording information, must be carried out properly and fairly. Fulfillment of obligations to humans and the environment (horizontal accountability), by balancing the goals the organization wants to achieve with individual goals and paying attention to the welfare aspects of stakeholders both to amil, society, and other parties. In addition, accountability in OPZ is also related to the concept of justice in achieving the organizational goals of zakat institutions, by paying attention to the welfare of employees and the community by realizing justice. Fair behavior can be exemplified in terms of providing salary and bonus treatment to employees according to the employee's aspect as amil zakat (Apriyanti, 2017).

Based on the explanation above, it can be defined that accountability in zakat management organizations is the level of success in the realization of the duties of a zakat organization unit or amil body to be accountable for the management, distribution and control of sources of zakat funds and the implementation of policies mandated by muzakki as a form of achieving goals that have been formulated through accountability media within a certain period of time and carrying out their obligations based on standard norms and professional ethics (Nurfida, 2015).

\subsection{Hypotesis Development}

Organizational commitment within the zakat management organization affects the behavior of an amil to take actions that obey the rules and are accountable. This is because amil has a high loyal attitude towards superiors or the organization that supports him. Based on the Theory of Planed Behavior (TPB), personal values in the form of intention and loyalty possessed by amil are considered more accurate in predicting actual behavior. Organizational commitment at OPZ is defined as a characteristic of loyalty and acceptance of the goals and values of an organization. (Maghfiroh et al. 2012) revealed that organizational commitment has a positive effect on accountability of OPZ. Based on the description, the hypothesis is proposed as:

\section{a) H1: Organizational commitment has a positive effect on accountability of OPZ}

Organizational culture in zakat management organizations includes a system that contains norms of behavior, patterns of social and moral assumptions adopted by each individual in order to direct their actions in achieving organizational goals. Organizational culture is deliberately developed by groups with the aim of shaping daily behavior within the organization in carrying out work and making decisions. In the perspective of SET (Sharia Enterprise theory), the accountability of amil is said to be balanced if in carrying out his duties 
besides paying attention to social values must also pay attention to the value of sharia. (Christina, et al. 2012) revealed that organizational culture has a positive influence on the accountability of OPZ. Based on this description, the hypothesis is proposed as:

\section{b) H2: Organizational culture has a positive effect on accountability of OPZ}

Based on fund theory, the main focus in zakat management organizations is that the use of zakat funds must demonstrate accuracy of targets and adequate legal and economic restrictions. The administration and use of assets of the amil body must be independent and on target by collecting a list of zakat recipients, recording a series of cash accounts, and or other accountable and actual sources of funds to later be used as the basis for recording accounts in financial statements which will then be presented to muzakki. According to (Primadoni et al. 2014), the clarity of budget targets partially has a positive and significant effect on the accountability of non-profit organizations. Thus, the hypothesis is proposed as;

\section{c) H3: Clarity of budget targets has a positive effect on Accountability of OPZ}



Fig. 1 Research Framework

\section{Research Method}

This type of research used causal research which is intended to uncover problems in the form of cause and effect. Researchers use research designs to provide empirical evidence and analyze organizational commitment, organizational culture and clarity of budget targets which affect the performance accountability in zakat management organizations. Based on the characteristics of the problem, this research is a correlational research, which is research involving the activities of collecting data used to determine whether there is a relationship between the independent and dependent variables. This study used primary data, which data obtained from original sources. The research data obtained from the informants by distributing questionnaires to respondents to answer in according to the circumstances.

The population of this research is the zakat management organization in Semarang, Central Java, Indonesia. Samples were taken using purposive sampling and were taken from zakat management organizations in Central Java which have the following criteria, which are registered as Islamic social organizations or foundations that manage the field of preaching and social affairs, have sharia supervisors, are non-profit, have an organizational structure consisting of supervisors, chairman of members and chairman of the Sharia board, get recommendations from BAZNAS, have a program to utilize zakat for the welfare of the society, have financial reports that are audited regularly, have a source of zakat receipts above IDR. 500,000,000, 00 per year.The data collection method in this study used a questionnaire. 
The type of questionnaire used is a closed questionnaire using 5 Likert scales, which point 1 for STS (strongly disagree), point 2 for TS (disagree), point 3 for $\mathrm{N}$ (neutral), point 4 for S (agree), and point 5 for SS (strongly agree).

This study used primary and secondary data. Primary data was obtained by distributing a questionnaire directly to find out the operational activities of the OPZ. Primary data were obtained directly through observation, documentation and questionnaires. Researchers make observations (field surveys) to the object of research by distributing questionnaires directly to the parties involved in the management of zakat. A total of 50 questionnaires were distributed proportionally to the National Zakat Agency (BAZNAS) of Semarang, Aksi Cepat Tanggap Semarang, Lazis Muhammadiyah Semarang, Dompet Dhuafa Semarang, and Lazis Sultan Agung Semarang.

\subsection{Measurement of Each Variable}

Table 1. Measurement of Accountability of OPZ

\begin{tabular}{|c|c|c|}
\hline Dimensions & Measurement of Variable & Source \\
\hline \multirow[t]{2}{*}{ Reporting } & $\begin{array}{l}\text { The zakat management organization has an internal reporting } \\
\text { system and external reporting aimed at top management and } \\
\text { supervisory authorities. }\end{array}$ & \\
\hline & $\begin{array}{l}\text { Financial reporting forms and transactions that must be } \\
\text { reported regularly are available. }\end{array}$ & \\
\hline \multirow[t]{3}{*}{ Assessment } & $\begin{array}{l}\text { Zakat administrators use generally accepted accounting } \\
\text { standards and rules. }\end{array}$ & \\
\hline & $\begin{array}{l}\text { Zakat supervisors assess the compliance of zakat institutions } \\
\text { with Sharia regulations and other legal requirements. }\end{array}$ & $\begin{array}{l}\text { Zakat Core } \\
\text { Principle }\end{array}$ \\
\hline & $\begin{array}{l}\text { The management system at OPZ includes analysis of } \\
\text { financial reports and accounts, sharia compliance analysis, } \\
\text { collection model analysis and distribution model analysis. }\end{array}$ & \\
\hline \multirow[t]{2}{*}{ Accountability } & $\begin{array}{l}\text { Zakat administrators use an integrated IT system to support } \\
\text { the reporting system. }\end{array}$ & \\
\hline & $\begin{array}{l}\text { The zakat management organization publishes a list of } \\
\text { financial reports that are easily accessible to the public. }\end{array}$ & \\
\hline & able 2.Measurement of Organizational Commitment Variable & \\
\hline Dimensions & Measurement of Variable & Source \\
\hline \multirow{3}{*}{$\begin{array}{l}\text { Orientation on } \\
\text { individual }\end{array}$} & Amil works optimally because he puts his job as a profession. & \\
\hline & $\begin{array}{l}\text { Zakat Organization is willing to be provided with guidance by } \\
\text { OPZ. }\end{array}$ & \\
\hline & $\begin{array}{l}\text { Zakat organization is satisfied with the salaries, benefits, } \\
\text { positions and incentives provided by OPZ. }\end{array}$ & $\begin{array}{l}\text { Book of Zakat } \\
\text { Guide (2015) }\end{array}$ \\
\hline
\end{tabular}






Table 4. Measurement of Clarity of Budget Objectives Variable

\begin{tabular}{|c|c|c|}
\hline Dimensions & Measurement of Variable & Source \\
\hline \multirow[t]{2}{*}{ Regulation } & $\begin{array}{l}\text { Zakat institutions have financial planning, records and } \\
\text { management to prevent inappropriate allocation of fund } \\
\text { distribution. }\end{array}$ & \\
\hline & $\begin{array}{l}\text { The zakat management organization has indicators of social } \\
\text { benefits } \\
\text { to be accomplished. }\end{array}$ & \\
\hline \multirow[t]{2}{*}{ Period of time } & $\begin{array}{l}\text { Zakat funds will be distributed as soon as possible on a } \\
\text { consumptive basis or on a productive basis. }\end{array}$ & $\begin{array}{l}\text { Zakat Core } \\
\text { Principle }\end{array}$ \\
\hline & $\begin{array}{l}\text { Zakat funds from the most recent collection period must be } \\
\text { distributed for a maximum of } 1 \text { year. }\end{array}$ & \\
\hline \multirow[t]{2}{*}{ Priority Goals } & $\begin{array}{l}\text { Zakat funds are distributed based on priority after taking into } \\
\text { account the principles of fairness, and territorial proximity }\end{array}$ & \\
\hline & $\begin{array}{l}\text { Zakat recipient is clearly determined by the zakat supervisor } \\
\text { and informed to the public. }\end{array}$ & \\
\hline
\end{tabular}




\subsection{Data Analysis Method}

This study used a quantitative approach. The analytical method used in this research is statistical analysis and the calculations are carried out using SPSS 23. The analysis model used in this study to analyze the effect of independent variables on the dependent variable used multiple linear regression. This statistical analysis model was chosen because this study was designed to examine the independent variables that affect the dependent variable.

The equation for multiple linear regression analysis is as follows:

$$
\mathrm{Y}=\mathrm{a}+\mathrm{b}_{1} \mathrm{X}_{1}+\mathrm{b}_{2} \mathrm{X}_{2}+\mathrm{b}_{3} \mathrm{X}_{3}+\mathrm{e}
$$

\begin{tabular}{lll}
$\mathrm{Y}$ & $:$ & Accountability \\
$\mathrm{a}$ & $:$ & Constant \\
$\mathrm{b}_{1}, \mathrm{~b}_{2}, \mathrm{~b}_{3}:$ & \multicolumn{2}{c}{ Coefficient of $\mathrm{X}_{1, \mathrm{X} 2}, \mathrm{X}_{3}$} \\
$\mathrm{X}_{1}$ & $:$ & Organizational Commitment \\
$\mathrm{X}_{2}$ & $:$ & Organizational culture \\
$\mathrm{X}_{3}$ & $:$ & Clarity of Budget Objectives \\
$\mathrm{e}$ & $:$ & error
\end{tabular}

\section{Result and Discussion}

The object of research in this study is the zakat management organization in Semarang. Total samples taken were 50 respondents using purposive sampling technique. The data used are primary data by distributing questionnaires for 5 weeks starting December 25, 2019 to January 31,2020 . The number of questionnaires distributed is 70 questionnaires. Of the total number of questionnaires, there were 56 questionnaires returned and 50 questionnaires that met the criteria, while 6 questionnaires did not meet the criteria. The identities of the 50 samples were grouped according to gender, level of education, age, managerial position, and length of service for each respondent.

\begin{tabular}{lcc}
\multicolumn{2}{c}{ Table 5. Characteristics of Respondent Position } \\
\hline Characteristics & Frequency & Percentage \\
\hline Sharia Council & 3 & $6 \%$ \\
Director & 1 & $2 \%$ \\
Front Office & 4 & $8 \%$ \\
Fundraising & 5 & $1 \%$ \\
Communication & 1 & $2 \%$ \\
Manager & 3 & $6 \%$ \\
Supervisor & 3 & $6 \%$ \\
Caretaker & 5 & $10 \%$
\end{tabular}




\begin{tabular}{lcc}
\hline Characteristics & Frequency & Percentage \\
\hline Leader & 2 & $4 \%$ \\
Volunteer & 2 & $4 \%$ \\
Staff & 19 & $38 \%$ \\
Program Staff & 1 & $2 \%$ \\
\hline Total & $\mathbf{5 0}$ & $\mathbf{1 0 0} \%$ \\
\hline
\end{tabular}

The list of respondents who filled out the questionnaire data directly consists of several levels of managerial positions in the OPZ structure, including sharia boards, directors, front office, fundraising, communications, managers, supervisors, administrators, leaders, volunteers, office staff, and program staff. From the processed statistical data, it can be concluded that adequate validity was obtained because the statements in the questionnaire were filled in by respondents according to their respective responsibilities at each managerial level.

Table 6. Characteristics of Respondents' Length of Work

\begin{tabular}{ccc}
\hline Characteristics & Frequency & Percentage \\
\hline 1 year & 16 & $32 \%$ \\
10 months & 2 & $04 \%$ \\
2 years & 12 & $24 \%$ \\
3 years & 11 & $22 \%$ \\
4 years & 2 & $4 \%$ \\
5 years & 5 & $10 \%$ \\
6 months & 2 & $04 \%$ \\
\hline Total & $\mathbf{5 0}$ & $\mathbf{1 0 0} \%$ \\
\hline
\end{tabular}

Respondents with a work period of 1 year had the highest percentage $(32 \%)$, then in the second position were respondents with 2 years of service $(24 \%)$. It can be concluded that based on the respondent's data, adequate validity is obtained because the respondent has a good knowledge of the managerial organization based on their experience while serving in OPZ. According to Foster (2001), the length of time a person has taken makes him more aware of his duties and position in the organization than members who have already joined.

Table 7. Descriptive Statistics

\begin{tabular}{lccccccc}
\hline \multicolumn{7}{c}{ Table 7. Descriptive Statistics } \\
& N & $\begin{array}{c}\text { Total } \\
\text { Indicator }\end{array}$ & Min & Max & Mean & Median & $\begin{array}{c}\text { Std. } \\
\text { Deviation }\end{array}$ \\
\hline $\begin{array}{l}\text { Accountability of } \\
\begin{array}{l}\text { Zakat Management } \\
\text { Organization }\end{array}\end{array}$ & 50 & 7 & 25 & 35 & 30,14 & 29,50 & 2,680 \\
\end{tabular}




\begin{tabular}{lccccccc}
\hline & N & $\begin{array}{c}\text { Total } \\
\text { Indicator }\end{array}$ & Min & Max & Mean & Median & $\begin{array}{c}\text { Std. } \\
\text { Deviation }\end{array}$ \\
\hline $\begin{array}{l}\text { Organizational } \\
\text { Commitment }\end{array}$ & 50 & 5 & 17 & 30 & 25,10 & 25,00 & 2,558 \\
$\begin{array}{l}\text { Organizational } \\
\text { culture }\end{array}$ & 50 & 6 & 16 & 30 & 25,00 & 25,00 & 2,727 \\
$\begin{array}{l}\text { Clarity of Budget } \\
\text { Objectives }\end{array}$ & 50 & 6 & 6,0 & 25 & 25,10 & 25,00 & 3,493 \\
\hline
\end{tabular}

Based on the results of descriptive statistical analysis, it shows that the number of respondents $(\mathrm{N})$ is 50 respondents. The accountability variable of the Zakat Management Organization with a minimum value of 25 and a maximum value of 35 . It has mean value of 30.14 and a standard deviation value of 2,680, the median value of 29.50 . The mean value is $30.14>29.50$ of median value, it means that the accountability variable of the zakat management organization is high. The variable of organizational commitment has a minimum value of 17 and a maximum value of 30 . The mean value is 25.10 , the standard deviation is 2.558 , and median value is 25.00 . It can be concluded that if the mean value is $25.10>25.00$ of median value, the variable of organizational commitment is said to be high. The organizational culture variable has a minimum value of 16 and a maximum value of 30 . The mean value is 25.00 , the standard deviation value is 2.727 , and the median value is 25.00 . It can be concluded that the mean value of $25.00>25.00$ of median value for the organizational culture variable is said to be high. The variable of budget target clarity has a minimum value of 6.0 and a maximum value of 25 . The mean value is 25.10 and the standard deviation value is 3.493 and the median value is 25.00 . It can be concluded that the mean value $25.10>25.00$ of median is that the variable of clarity of budget targets is said to be high. Based on the results of the discussion, it can be said that all the dependent and independent variables have high results.

\subsection{Classical Assumption Test Results}

Table 8. Classical Assumption Test Results

\begin{tabular}{lccccc}
\hline & $\mathbf{A}$ & $\mathbf{X}_{\mathbf{1}}$ & $\mathbf{X}_{\mathbf{2}}$ & $\mathbf{X}_{\mathbf{3}}$ & $\mathbf{Y}$ \\
\hline $\mathrm{B}$ & 5,980 & 0,323 & 530 & -214 & $\begin{array}{c}\text { Accountability } \\
\text { of OPZ }\end{array}$ \\
$\mathrm{A}$ & 0,000 & 0,045 & 0,026 & 0,167 & \\
$\mathrm{~T}$ & 4,126 & 2,075 & 2,335 & $-1,413$ & \\
$\mathrm{~F}$ & \multicolumn{5}{c}{$\mathrm{F}$ test $=3,160 \alpha=0,037$} \\
$\mathrm{R}^{2}$ Adjusted & \multicolumn{5}{c}{0,194 or $19,4 \%$} \\
$\begin{array}{l}\text { Normality / Kolmogorov } \\
\text { smirnov }\end{array}$ & \multicolumn{5}{c}{$0,200>0,05$} \\
Heteroscedasticity & 0,746 & 0,914 & 0,416 & 0,591 &
\end{tabular}




\begin{tabular}{|c|c|c|c|c|c|}
\hline & $\mathbf{A}$ & $\mathbf{X}_{1}$ & $\mathbf{X}_{2}$ & $\mathbf{X}_{3}$ & $\mathbf{Y}$ \\
\hline Dependent Variable & \multicolumn{4}{|c|}{ ABS_RES } & \\
\hline \multicolumn{6}{|l|}{ Multicollinearity } \\
\hline Tolerance & & 0,987 & 0,818 & 0,809 & \\
\hline VIF & & 1,013 & 1,222 & 1,236 & \\
\hline
\end{tabular}

The normality test has a significant value of $0.200>0.05$, so it can be concluded that the data tested is normally distributed. The multicollinearity test results on the organizational commitment variable with a VIF value of $1.013<10$ and a tolerance value of $0.987>0.10$, so there is no multicollinearity. The organizational culture variable has a VIF value of $1.222<10$ and a tolerance value of $0.818>0.10$, so there is no multicollinearity. The budget target clarity variable has a VIF value of $1.236<10$ and a tolerance value of $0.809>0.10$, so there is no multicollinearity. It can be concluded that the regression model is suitable for the use in conducting research testing. Based on the results of statistical data processing, the heteroscedasticity test results show that the organizational commitment variable has a sig. value of $0.914>0.05$, which means that there is no heteroscedasticity. The organizational culture variable has a sig. value of $0.417>0.05$, which means that there is no heteroscedasticity. The variable budget target clarity has a sig. value of $0.591>0.05$, which means that heteroscedasticity does not occur. From the results of the Glejser test, it can be concluded that all independent variables used in this study did not occur heteroscedasticity as evidenced by the significance value of all independent variables $>0.05$.

\subsection{Multiple Linear Regression Analysis}

The constant in the regression calculation is 5,950, indicating that if the variables of organizational commitment, organizational culture and clarity of budget targets are constant, it is stated that the increase in the accountability of the zakat management organization is 5,950. The regression coefficient for organizational commitment is 323 which is positive, meaning that each increase in organizational commitment is followed by an increase in the accountability of the zakat management organization. The regression coefficient for organizational culture of 530 is positive, so any increase in organizational culture will be followed by an increase in the accountability of the zakat management organization. The regression coefficient for clarity of budget targets is negative, any increase in clarity of budget targets is not followed by an increase in the accountability of zakat management organizations.

$\mathrm{Y}=5,950+0,323 \mathrm{X}_{1}+530 \mathrm{X}_{2}-214 \mathrm{X}_{3}+\mathrm{e}$

\subsection{Hypothesis Test Results}

Based on table 8 , the results of the $\mathrm{F}$ test show that the calculated $\mathrm{F}$ value is 3,160 with a significance value of $0.037<0.05$ so that the variables of organizational commitment, organizational culture, and clarity of budget targets simultaneously have an effect on accountability of OPZ. Based on table 7, the coefficient of determination test results obtained an Adjusted $\mathrm{R}^{2}$ Square value of 0.194 or $19.4 \%$, which means that the independent variables 
(organizational commitment, organizational culture and clarity of budget objectives) can affect the dependent variable (accountability of OPZ) by $19.4 \%$.

From this study, the results show that organizational commitment has a significant positive effect on accountability of OPZ with a significance value of $0.045<\alpha=0.05$ and the regression coefficient $(\beta)$ value of the organizational commitment variable has a positive value of 0.323 . It can be concluded that the first hypothesis, namely organizational commitment has a significant positive effect on accountability of OPZ is accepted, meaning that if amil has good organizational commitment, it will increase accountability of OPZ.

The effect of the organizational commitment variable on the accountability of OPZ variable is the attitude of totality, professionalism and trustworthiness of amil related to the ability of the organization to provide accountability that is presented both to Allah SWT, muzakki, the public and nature. Amil, who is committed to carrying out his duties optimally and obeying the rules, applying sharia rules or general regulations and not ignoring any standards, principles and systems that apply within the organization, so that this can increase the accountability of OPZ.

The relationship between the theory of planed behavior (TPB) and organizational commitment is that when amil has personal values in the form of intention and loyalty, amil will carry out his duties according to the goals and values that exist within the organization to the fullest. Organizational commitment within the zakat management organization influences the behavior of amil in taking action that obeys the rules and is accountable. This research is in line with the research conducted by Setyorini et al. (2015), Nurji et al. (2019), and Ajurna et al. (2019) who argue that organizational commitment has a positive effect on accountability of OPZ. However, this study is not in line with the research conducted by Hardiyanto et al. (2016) who argue that organizational commitment does not have a significant effect on accountability of OPZ. This is due there is the possibility of different job satisfaction in each amil even though they get a division of labor, salary, or facilities that are suitable for their work. Amil who does not have job satisfaction in the organization is unable to create loyalty, prudence, and cannot coordinate optimally with the team at work so that this can affect the accountability of OPZ.

Organizational Culture has a significant positive effect on Accountability of OPZ with a significance value of $0.026<\alpha=0.05$ and the regression coefficient $(\beta)$ value of the organizational culture variable has a positive value of 530. It can be concluded that the second hypothesis is that organizational culture has a positive effect on accountability of OPZ is accepted, meaning that a good organizational culture will increase accountability of OPZ. In this study, the effect of organizational culture variable on the accountability of OPZ variable, which is the habits and behavior of amil that are deliberately created and continuously repeated so that they become patterns in the organization in the form of formal or informal practices, physical arrangements or customs, one of which aims to shape the behavior of members according to the rules. Organizational strength is used as a measure of the quality of the organizational members. If the quality of the members of the organization is high, it will increase the accountability of OPZ.

The relationship between sharia enterprise theory (SET) and organizational culture is that when carrying out his duties, amil must pay attention to social values and sharia values in behavior. These values are internalized into various kinds of actions while still considering their suitability with the applicable law so that there is no conflict between sharia law and social law. The better the organizational culture in the OPZ, the more directed and controlled the behavior of amil will be according to the regulations so that the obedience of amil will be higher. 
This research is in line with research conducted by Arjuna et al. (2019), Christina, et al. (2012) and Setyorini, et al. (2015) who argue that organizational culture has a significant positive effect on accountability of OPZ. However, this study is not in line with research conducted by Hamidi (2015) which shows that organizational culture has no effect on accountability of OPZ. This is because the accountability of OPZ is not entirely determined by the organizational culture, but there are other factors that have a direct effect, for example the systems and procedures adopted by one organization vary. The results show that the clarity of budget targets has a negative and insignificant effect on accountability of OPZ with a significance value of $0.167>\alpha=0.05$. While the value of the $\beta$ coefficient of the clarity of the budget target is negative, that is -214 . It can be concluded that the clarity of budget targets has a negative and insignificant effect on accountability of OPZ, meaning that the results of this study are different from the hypothesis.

The descriptive statistical data of this study, namely the variable of clarity of budget targets, has 6 question items and used a 5-point Likert scale so that the maximum value is 25 and the minimum value is 6 . The mean value of 25.10 is greater than the median value of 25 in the accountability of OPZ variable, there are 7 question items with a maximum value of 35 and mean value of 30.14 which is greater than the median value of 29.50 . These data indicate that there is a mismatch between descriptive statistics, research hypotheses and hypothesis test results so that the clarity of budget targets does not have a significant effect on accountability of OPZ. The results of the interview with the leaders of ACT (Aksi Cepat Tanggap Semarang) and the LazisMU Management (Lazis Muhammadiyah Central Java) stated that the zakat fund budget cannot be allocated clearly at the beginning of the period because at this time, OPZ prioritizes the distribution of zakat funds for emergency situations, for example, natural disasters, wars or due to unpredictable eviction of residential areas. This condition resulted in the distribution of zakat funds out of the equity and territorial principles.

This study is in line with the research of Laksana, et al. (2014). However, this research is not in line with the research conducted by Primadoni, et al (2014) and Nurji et al. (2019) who argue that clarity of budget requirements has a significant effect on increasing the accountability of OPZ. Because the clarity of budget targets reflects the extent to which budget targets are stated specifically, clearly, and can be understood by the amil who is responsible for compiling and implementing them. Therefore, the clarity of budget targets can increase the accountability of OPZ.

\section{Conclusion}

Organizational Commitment has a significant positive effect on Accountability of OPZ, the hypothesis is accepted. The attitude of totality, professionalism, and trustworthiness of amil is related to the ability of the organization to provide accountability to Allah, muzakki, the public and nature. Amil, who is committed to carrying out his duties optimally and obeying the rules, applying sharia rules or general regulations, and not ignoring any standards, principles and systems that apply in the organization, so that this can increase accountability of OPZ. Organizational Culture has a significant positive effect on the Accountants for OPZ Accountants, the hypothesis is accepted. The habits and behaviors of amil are deliberately created and repeated continuously until they become patterns in organizations in the form of formal or informal practices, physical arrangements or manners, one of which aims to shape the behavior of members according to the rules. Organizational culture is used as a measure of 
the quality of organizational members. If the quality of the members of the organization is high, it will increase the accountability of OPZ.

Clarity of budget targets has a negative and insignificant effect on OPZ accountability, the hypothesis is rejected. The zakat fund budget cannot be allocated clearly at the beginning of the period because at present the OPZ prioritizes the distribution of zakat funds for emergency situations, such as natural disasters, wars or due to unpredictable evictions of residential areas. This condition resulted in the distribution of zakat funds out of the equity and territorial principles.

\section{Implications}

For the Zakat Management Organization (OPZ), it is better if the recruitment of amil takes into account the qualification of the position requirements that will be filled according to the prevailing organizational culture and commitment, so that competent Amil is obtained in every managerial position, especially in the position of chief accounting. By having a reliable accountant, the OPZ can prepare clarity of budget targets well. Amil can increase organizational commitment and organizational culture by adding insight, skills, knowledge and skills through sharia certification, participating in training, comparative studies between similar organizations and updating standards regarding regulations governing non-profit, social or religious organizations. Therefore, amil can better recognize his duties or position in the organization and distribution of ZIS funds as a form of organizational responsibility. The Government should coordinate with the IAI (Indonesian Accountants Association) to establish a definite team regarding the recording and reporting procedures for ZIS funds in OPZ which have adopted sharia principles in it. Thus, OPZ has a definite standard for preparing clarity of budget targets at the beginning of the period. For Academics Knowledge of sharia accounting and non-profit accounting in society, it still needs to be improved. From the distribution of questionnaires and interviews that the researchers conducted, it was concluded that some OPZ administrators did not know for sure about PSAK 09 which discusses grants, alms, and zakat. Academics need to provide learning to students about Islamic accounting so that graduates have the qualifications and insight into Islamic accounting.

\section{References}

[1] Apriyanti, H. W. (2018). Teori Akuntansi Berdasarkan Pendekatan Syariah. Sleman: Depublish Publisher.

[2] Apriyanti, H. W. (2017). Islamic Social Finance Accountability Practice. IJEBE.

[3] Arjuna, A. M., et al. (2019). Akuntanbilitas kinerja instansi pemerintah. Jurnal Akuntansi dan Ekonomika.

[4] Bestari, L. d., et al. (2014). PENGARUH KEJELASAN SASARAN ANGGARAN, Pengawasan fungsional, dan Ppelaporan kinerja terhadap Akuntabilitas. Accounting Analysis Journal, 2252-6765.

[5] Colquitt, J. A. (2015). Organizational Behavior. United States Of America: Me Graw Hill Education.

[6] Endahwati, Y. D., et al. (2014). Pengelolaan Zakat, Infaq, Sadaqah (ZIS). Jurnal Ilmiah Akuntansi, 2089-3310. 
[7] Firmansyah., et al. (2016). Syariah Enterprise Theory, Implementasi \& Pengaruhnya Terhadap Kepuasan \& Loyalitas Nasabah Perbankan syariah di malang. Laporan Penelitian Kompetitif.

[8] Fitria, Y., et al (2017). Akuntanbilitas Pada Organisasi Religi. ISSN, 0216 - 7743.

[9] Ghozali. (2016). Teknik Penyusunan Skala Likert dalam Penelitian Akuntansi \& Bisnis.

[10] Hakim, R., et al. (2017). Implementasi Nilai Amanah dalam Organisasi Pengelola Zakat Untuk Mengurangi Kesenjangan \& Kemiskinan. Jurnal Ekonomi Syariah , 2580 4669.

[11] Hamidi, N., et al. (2013). Analisis Akuntanbilitas Publik Organisasi Pengelola Zakat Berdasarkan Aspek Pengendalian Intern dan Budaya Organisasi. ISSN, 1907 - 9709.

[12] Hardiyanto, W. (2018). Measurment Of The Performance and accountability of Zakah Organizations in Yogyakarta. ISSN, 2528-1194.

[13] Indonesia, D. A. (2006). Al Quran Al Karim dan Terjemahannya,Kudus: Menara Kudus.

[14] Indonesia, I. A. (2010). Standar Akuntansi Keuangan PSAK No. 109 Akuntansi Zakat, Shodaqoh dan Infaq. jakarta: Salemba Empat.

[15] Keyton, J. ( (2005). Communication and Organizational Culture. United Kingdom: : Sage Publications, Inc.

[16] Khasandi, E. A. ( 2019). The Influence of Zakah on Economic Growth and Walfare Society in Indonesia.

[17] Khikmah, S. (2005). Pengaruh Profesionalisme Terhadap Keinginan Berpindah dengan Komitmen Organsasi \& Kepuasan kerja. Maksi.

[18] Kusmiati., et al.(2015). Kelayakan Financial Usaha Tani. Agronomika, 2301-9948.

[19] Lesmana. (2017). Tax Complience ditinjau dari Theory Of Planed Behaviour (TPB) . . Jurnal Investasi .

[20] M. [1] Ag, D. H. (2012). Standar Operasional Prosedur OPZ . jakarta: Direktorat Pemberdayaan Zakat.

[21] M.Ag, D. H. (2009). Standar Operasional Prosedur OPZ. jakarta: Direktorat Pemberdayaan Zakat.

[22] Mardiasmo., et al.(2002). Hubungan Antara Pertumbuhan Ekonomi Daerah, belanja, Pembangunan dan Pendapatan Asli Daerah.

[23] Marlikan, M. (2012). Pengaruh Pembelajaran Organisasi dan Motivas. Jurnal Manajemen Bisnis.

[24] Mubtadi, N. A., et al. (2017). Akuntanbilitas Dalam Perspektive Akuntansi Syariah . Jurnal Ekonomi Syariah Indonesia.

[25] Nikmatuniayah., et al. (2017). Effect Of Accounting Information Quality, Accountability, and Transparancy On Zakat Acceptance Of zakah Fund. ISSN, 02158175 .

[26] Nurfida., et al. (2015). Analisis Akuntanbilitas Pengelolaan Zakat

[27] Nurhasanah, S. (2018). Akuntanbilitas Laporan Keuangan Lembaga Amil Zakat dalam Memaksimalkan Potensi Zakat. ISSN, 2461 - 1190.

[28] Nurji, T. a. et al. (2019). Pengaruh kejelasan sasaran anggaran, sistem pelaporan terhadap akuntanbilitas pemerintah dan komitmen organisasi sebagai variabel moderating. Jurnal Akuntansi, 2302 - 8556.

[29] Primadoni, N. K., et al. (2014). Pengaruh Kejelasan Sasaran Anggaran dan Efektivitas Pengendalian internal Terhadap Akuntanbilitas Kinerja Instansi Pemerintah. E Journal. 
[30] Prof. Dr. Imam Ghozali., M. A. (2014). Teori Akuntansi. Semarang: Universitas Diponegoro.

[31] Putra, D. (2013). Pengaruh Akuntanbilitas Publik \& Kejelasan Sasaran Anggaran Terhadap Kinerja Manajerial Satuan Kerja Perangkat Daerah. Jurnal Akuntansi.

[32] R Wayne Dean Mondy, Josep J Martochio. (2016). Human Resource Management Global Edition. England: Business Publising.

[33] Rasul, s. (2010). Secret of a serial enterpreneur a business dragons guide to succes. United Kingdom: Capstone Publising Ltd.

[34] Rehman, P. J. (2011). Islamic law of obligatory alms. UKCLE.

[35] Setiawan, E., et al. (2013). Pengaruh Kejelasan Sasaran Anggaran, Pengendalian Akuntansi, dan Sistem Pelaporan Terhadap Akuntanbilitas Kinerja Pemerintah.

[36] Shirazi, P. D. (2016). Core Principles For Affective Zakat Supervision.

[37] Siswati, E. (2015). Model Akuntanbilitas Organisasi Non Profit Pada Masjid . Jurnal Riset \& Aplikasi, 29-41.

[38] Siti Aisyah, J. J. (2020). Pengaruh kompetensi aparat dan komitmen organisasi terhadap implementasi sistem akuntanbilitas pemerintah. Indonesia accounting journal, $110-117$

[39] Sugiono. (2010). Metode Penelitian Bisnis. Bandung: Alfabeta.

[40] Suharono. (2006). Pengaruh Kejelasan Sasaran Anggaran, Pengendalian, Akuntansi dan Sistem Pelaporan Terhadap Kinerja .

[41] Tri, C. (2012). Pengaruh Komitmen Organisasi, Budaya Organisasi dan Keterlibatan Kerja Terhadap Kinerja Karyawan BMT. ISSN, 2088 - 2106.

[42] Triyuwono, I. (2001). Akuntansi Syariah. Salemba Empat.

[43] Zakiy, M. et al. (2016). Analisis Persyaratan Substantif teknis \& administrasi dalam rangka penerapan pola pengelolaan badan keuangan. Jurnal Ilmiah Mahasiswa FEB .

[44] Saad. (2014). Analisis Akuntanbilitas Pengelola Zakat dengan Pendekatan Trilogi.

[45] Schein, E. H. (2004). Organizational Culture and Leadership . San Francisco: Jassey Bass Publised. 